\title{
RELATIONSHIP BETWEEN MISCONCEPTION AND MATHEMATICAL ABSTRACTION OF GEOMETRY AT JUNIOR HIGH SCHOOL
}

Gida Kadarisma*, Nelly Fitriani, Risma Amelia

Insititut Keguruan dan Ilmu Pendidikan Siliwangi, Indonesia

\begin{tabular}{l}
\hline \hline Article Info \\
\hline Article history: \\
Received Aug 21, 2020 \\
Revised Sep 20, 2020 \\
Accepted Sep 22, 2012 \\
\hline
\end{tabular}

\section{Keywords:}

Abstraction,

Geometry,

Misconception

\begin{abstract}
This study aims to examine the misconceptions that often occur in junior high school students on the concept of geometry based on abstraction level. The research method is qualitative with a case study design. Subjects in this study are 27 students of the 3rd grade of junior high school students, who had to learn all the concepts that will be appeared on the test. Material that will be given on the test of this research is the concept of Triangle, Quadrilateral, Flat Side Geometry and Curved Side Geometry. This research takes a place at one of the junior high schools in Cimahi. The instrument in this study is a diagnostic test (to find out the types of students' misconception), mathematical abstraction tests (to determine the level of abstraction) and interview rubrics. Misconceptions produced by students are closely related to students' mathematical abstractions, the higher the level of abstraction ability, the more students away from misconceptions. The topic taken in this study is the topic of basic geometry, the results can be a source of information about the types of misconception that often occur in students, and how the solution so that these misconception do not re-occur.
\end{abstract}

Copyright $(2019$ IKIP Siliwangi. All rights reserved.

\section{Corresponding Author:}

Gida Kadarisma,

Departement of Mathematics Education,

Institut Keguruan dan Ilmu Pendidikan Siliwangi,

Jl. Terusan Jenderal Sudirman, Cimahi, West Java 40526, Indonesia.

Email: gidakadarisma@ikipsiliwangi.ac.id

\section{How to Cite:}

Kadarisma, G., Fitriani, N., \& Amelia, R. (2020). Relationship between misconception and mathematical abstraction of geometry at junior high school. Infinity, 9(2), 213-222.

\section{INTRODUCTION}

Geometry is a part of mathematics, geometry has an important role to several things, for instance by studying geometry, it will increase logical thinking and the ability to make proper generalizations; better understanding on arithmetic, algebra , and calculus; getting a further learning; accelerating the mental development of students (Novita et al., 2018). But unfortunately, geometry is one the topic of mathematical which experiencing problems. The Performance of students in geometry reportedly very bad and is already supposed to be a concern for teachers of mathematics, the parents and the government (Adolphus, 2011). Poor performance is indicated by the wrong answers that are often made by students.

The types of error that are often made by students are very important to know, classify and examine the causes, so that learning can be more effective. Based on this , 
researchers want to identify the type of error that made the students of Junior High School and to investigate the possibility of the cause of the error, the reliable hypothesis emerge that the misconceptions is associated with the process of students' abstraction.

Misconceptions is a mistake in understanding the concepts or errors in interpreting the concept meaning (Ay, 2017). Misconception can also be interpreted by the cognitive structure inherent in a person but deviates from the actual conception. Misconceptions experienced by a person in learning mathematics will have a long impact on the subsequent understanding of mathematics. Because concepts in mathematics are not solitary, but are interrelated with one another. One basic concept of mistake, will lead someone to make other mistakes (Kadarisma, 2016). When someone is having misconception, it is different with what we called as "nescience". When a student experiences a misconception, in fact he has gone through the process of processing the information, only the way that might be wrong, some are memorizing immediately or some are wrong in interpreting so it leads to misconception. If the misconceptions happen during process of constructing the concept / structuring the cognitive experience, then the concept that is accepted will not be completely perfect and continuation for other concepts will be hampered. If it is not corrected immediately, it will become a serious problem.

The process of constructing the concepts is a process of mathematical abstraction. So between these two things certainly have a close relationship. It can be concluded that if a person experiences a misconception, there is a problem in the abstraction process experiences problems or even does not have this ability. So as to avoid misconceptions happening to students, the abstraction process conducted by students must be improved/ developed.

The ability of abstraction are in different levels from one to another or even there is student who does not have the ability. Fitriani (2018) modifies the levels of abstraction and indicators based on research that has been done by (Battista, 2007; Goodson-Espy, 1998; Hong \& Kim, 2016; Nurhasanah, 2018), among which are: Perceptual Abstraction/ Level 1 (Getting to Know the properties of mathematical objects based on the use of physical objects, Recognizing previous experiences related to the problem being faced); Internalization/ Level 2 (Representing the results of thought in the form of mathematical symbols, words, pictures, or diagrams; Interiorization/ Level 3 (Organizing (collecting, compiling, developing, and coordinating) concepts into new understanding or new knowledge), and Second level of Interiorization/ level 4 (generalizig new knowledge in a different context). Based on this theory, students experiencing misconceptions do not have the ability to mathematical abstraction or perhaps at the level of beginner/ pre levels of abstraction. When that happens, students have a tendency to solve problems with routine procedures (Hendriana, Prahmana, \& Hidayat, 2018), so perhaps a teacher/ teaching materials do not facilitate students to do so, but tend to directly provide formulas and do not coordinate the concepts with one to another.

Misconceptions include understanding or thinking which is not based on true information (Kusmaryono et al., 2020). According to Dayanti, Sugiatno, \& Nursangaji (2019), there are three types of misconceptions commonly done by students; classificational misconception, correlational misconceptions and theoretical misconceptions. Researchers are interested in analyzing the extent of misconceptions experienced by students in terms of the level of abstraction. According to this, researchers can recommend things that are considered capable to avoid students from misconceptions. 


\section{METHOD}

The research method of this research is qualitative with a case study design. The research subjects in this study are 27 students of 3rd grade of junior high school who had learned all the concepts that would be presented in the test, namely the concept of Triangles, Quadrilateral, Flat Side geometry and Curved Side geometry. The location in this study is in one of the junior high schools in Cimahi. The instrument in this study is set of question of diagnostic tests (to find out the types of difficulties that faced by students), mathematical abstraction tests (to determine the level of abstraction) and interview rubrics (as a form of data triangulation).

The research procedures are: 1) Students are given a test of mathematical abstraction (aims to find out the basic level of the students), 2) Students are given a special diagnostic test on the topic of geometry that has been explain previously (aims to find out the types of misconceptions / errors that are faced by students) and conduct interviews with some students who experiencing misconceptions. Data processing procedures: 1) Analyzing the abstraction level of students, 2) Examining the misconceptions of the students, 3) In depth analysis on the relation between the levels of abstraction and misconceptions done by students, 4) Concluding the phenomenon.

\section{RESULTS AND DISCUSSION}

\subsection{Results}

In this study, we obtained some data to be analyzed, including the percentage of students experiencing misconceptions based on their level of abstraction, (see Table 1).

Table 1. Level abstraction and types of misconceptions that are produced

\begin{tabular}{cccc}
\hline Mathematical Abstraction & \multicolumn{3}{c}{ Misconception Type (\%) } \\
\cline { 2 - 4 } & Theoretical & Classification & Correlational \\
\hline Level 1 (19 people) & 55.56 & 62.96 & 70.37 \\
Level 2 (5 people) & - & 7.41 & 3.70 \\
Level 3 (2 people) & - & - & - \\
Level 4 (1 person) & - & - & - \\
\hline
\end{tabular}

Based on Table 1, it appears that the subjects in this study are divided into several levels of abstraction ability, ranging from level 1 to level 4 . There are 4 students at level 3 and 1 Student at level 4. These two level show a limited number of students; it happens because the characteristics of students taken are from students with a basic to average level of ability. Students at levels 3 and 4 did not experience any misconception (see Table 1). They managed to answer the diagnostic test well. Students at levels 3 and 4 discover no errors in determining the elements in building space or getting up flat, they are also capable determine the relationship between concepts (between flat and shape Geometry), and they are able to explain problems such as height in a triangle.

In contrast to students at level $1,55.56 \%$ of students experiencing theoretical misconception, $62.96 \%$ experiencing classificational misconception and the largest is $70.37 \%$ in a correlational misconception. We can say that, students at that level experienced a lot of misconceptions. While at level 2 there are those who experience misconceptions but 
the percentage is not significant. There is a suspicion that the higher level of students' abstraction, the bigger possibility they will avoid any kind of misconception (see Table 1).

Furthermore, the students' error during the diagnostic test. Researchers try to analyze several possible reasons for errors, the result of the analysis leads to the low ability of mathematical abstraction (see Table 2).

Table 2. Types of misconceptions and forms of errors committed by students

\begin{tabular}{|c|c|c|}
\hline $\begin{array}{c}\text { Types of } \\
\text { Misconceptions }\end{array}$ & Mistake Made & Possible Reason \\
\hline \multirow[t]{5}{*}{ Theoretical } & $\begin{array}{l}\text { Error in determining the formula for } \\
\text { surface area and volume of space }\end{array}$ & $\begin{array}{l}\text { Do not understanding the } \\
\text { concepts of area and } \\
\text { volume, students only } \\
\text { memorizing the formulas. }\end{array}$ \\
\hline & $\begin{array}{l}\text { Error in understanding some formulas } \\
\text { for solid geometry }\end{array}$ & $\begin{array}{l}\text { Confusion using formulas } \\
\text { because they do not } \\
\text { understand the concept of } \\
\text { volume, do not understand } \\
\text { the relationship between } \\
\text { shapes, students only } \\
\text { memorizing the formulas }\end{array}$ \\
\hline & - Error determining height in triangle & $\begin{array}{l}\text { Students do not understand } \\
\text { high definition well and } \\
\text { lack of mastery of } \\
\text { prerequisite material }\end{array}$ \\
\hline & $\begin{array}{l}\text { - Mistakenly determined edge on } \\
\text { BRSL }\end{array}$ & $\begin{array}{l}\text { Does not have well } \\
\text { understanding on the } \\
\text { definition of edge, has weak } \\
\text { spatial ability }\end{array}$ \\
\hline & $\begin{array}{l}\text { Mistakenly determine the diagonal } \\
\text { plane and the diagonal plane on the } \\
\text { cube }\end{array}$ & Has weak spatial ability \\
\hline Classification & $\begin{array}{l}\text { Student error in classifying the types } \\
\text { of triangles }\end{array}$ & $\begin{array}{l}\text { Incomplete understanding } \\
\text { of the concept }\end{array}$ \\
\hline \multirow[t]{3}{*}{ Correlational } & $\begin{array}{l}\text { - Error in determining the relationship } \\
\text { between the concept of prism with } \\
\text { the concept of a cube, cuboid, or } \\
\text { cylinder }\end{array}$ & $\begin{array}{l}\text { Low ability to visualize, } \\
\text { low ability to construct } \\
\text { mathematical ideas }\end{array}$ \\
\hline & $\begin{array}{l}\text { Error in determining the relationship } \\
\text { between the concept of the pyramid } \\
\text { with the concept of cones }\end{array}$ & $\begin{array}{l}\text { Low ability to visualize, } \\
\text { low ability construct } \\
\text { mathematical ideas }\end{array}$ \\
\hline & $\begin{array}{l}\text { - Error in determining the relationship } \\
\text { between quadrilateral shapes }\end{array}$ & Low able to visualize \\
\hline
\end{tabular}

The following will examine some of the results of errors that have been made by students. First is classificational misconception, it happens first because students are not 
able to classify the types of triangles. If they being asked the types of triangles, students were only able to answer the Isosceles Triangle, Right Triangle, Equilateral Triangle, and Scalene Triangle. As shown in the sample of student's answers in Figure 1.

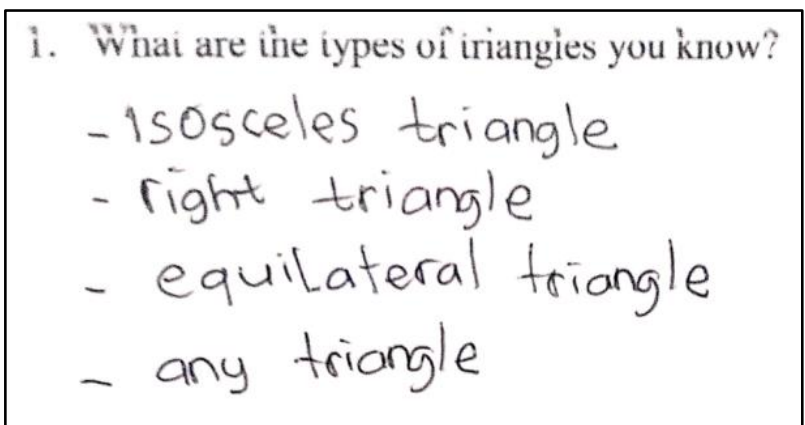

Figure 1. Sample of student's answers

Figure 1 show that an example of the answers of students who experience classificational misconceptions. Students cannot answer the types of triangles thoroughly. When teaching concepts about triangles, both the teacher and the textbook convey the concepts separately. Begin with the concept of Equilateral Triangle, Isosceles Triangle and Scalene Triangles, then focus on formulas to find area and circumference. After that, the review a little about the triangle based on the angle is given. This has become less balanced. Everything is given directly by the teacher and textbooks, not through the use of physical objects, and students are not given the opportunity to represent their observasion. So that the form of coordination between concepts is definitely not happening. Students do not experience a process of abstraction in finding the concept and experiencing a classificational misconception.

Furthermore, in the term of theoretical conception, students experience confusion in determining the height of a triangle if they are asked about the area of a triangle, as in Figure 2 .

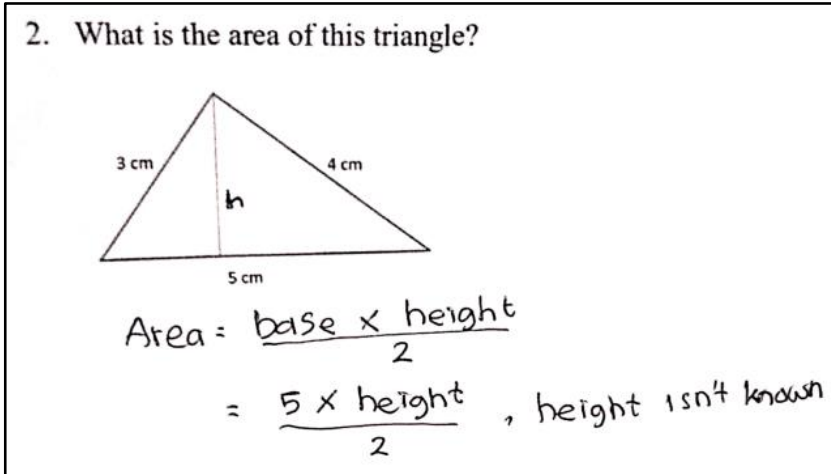

Figure 2. Sample of student's answers

Students experience misconceptions when working on these problems. Generally, they know that the concept of height in the triangle is a vertical line from the top to the base, there they do not understand the definition of height in depth (see Figure 2). If student examines the diagnostic problem that is given well, then the number shown will be triple phytagoras, so that between the shortest sides forming an angle of $90^{\circ}$ means that there is a concept of base and height to determine the area of a triangle.

Students experiencing other theoretical misconceptions and correlational misconceptions, this includes errors in explaining mathematical facts and also connecting concepts with one another (see Figure 3). 


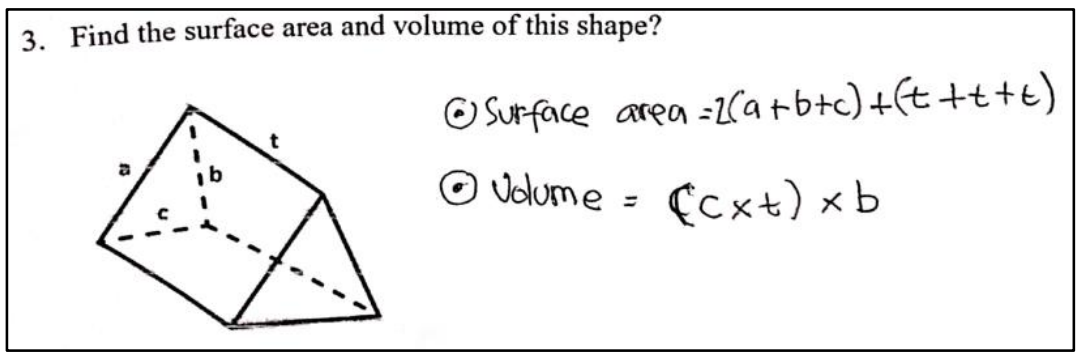

Figure 3. Sample of student's answers

Figure 3 show that students experience confusion in using the formula between the area of surface and the volume of solid geometry. In addition, students also feeling confuse in using the formulas of volume of solid geometry in solving a given problem. They have difficulty in memorizing all of these formulas, the demands given require students to memorize everything (not to understand it). This is reinforced by the results of the interview with one of the students (S1), following the interview excerpts conducted.

$\mathrm{T} \quad$ : Can you solve the problem?

S1 : Sure ma'am, it just sometimes I forgot the formula, hehehe ...

$\mathrm{T}$ : Why is that?

S1 : There are so many formulas, sometimes it is like being switched, even I already memorizing it.

Students do this is caused by several factors, one of which is that teachers teach concepts directly and the target of their learning is students must be able to work on the problems given. The books are used is also have a similar objective, the books contain a formula that ends with exercises. Both the teacher and the book that were designed, were only oriented towards the final results/ final test, and paid little attention to the occurrence of the concept formation.

In addition, the material conveyed tends to stand solitarily, not connected one to another, students do not recognize that the cube, cuboid, even the cylinder is included in the prism. Pyramid and cone was never be related one another. When students are asked whether a square is a rectangle, whether a rectangle is a parallelogram, whether the rhombus is a parallelogram, students generally answer no. This has triggered the emergence of correlational misconceptions. Students' understanding that they all stand alone (have each formula which is different and not related to each other (not have interconnected concepts). This is reinforced by the results of interviews with other students who experienced misconceptions (S2), following is part the interview:

$\mathrm{T} \quad$ : Why do you think that formulas of volume of the shape are many?

S2 : Yes there are indeed many, there are cube volumes, there are cuboid volumes, there are prism bolts, not to mention area of the square, the area of rhombus and others, it make me dizzy, it is too many and it so hard to memorize

$\mathrm{T} \quad$ : Do the shapes you mentioned earlier have different formulas?

S2 : Obviously different, ma'am, so I have difficulty in memorizing it

$\mathrm{T} \quad$ : Is there no relation between formula one and the other formula?

S2 : There is no ma'am 
: Are there the same properties between one shape and another, for example a square with rectangle?

S2 : (students just being quite and look confused ...)

\subsection{Discussion}

The results showed that there were students from various levels of abstraction who experienced different misunderstandings (see Table 1 and Table 2). As the level rises, students generally do not experience significant misconceptions. These results are in line with research conducted by Fitriani, Suryadi, \& Darhim (2018) that the low mathematical abstraction ability of junior high school students is highly correlated with the level of mathematical ability that is indeed in the lower category, so that the tendency when the level of abstraction is medium or low, they more often experience mathematical misconceptions.

Furthermore, researchers have described several types of errors that have been made by students when working on diagnostic test. The types of error made are categorized based on the types of misconceptions that have been mentioned previously, the errors generated are in line with the results of research conducted by Ozerem (2012). Based on the diagnostic tests, it turns out students at the low level of abstraction experience these 3 types of misconceptions; theoretical, correlational, and classificational misconceptions.

First is classificational misconception, this misconception happen because students are not able to classify the types of triangles. Generally, students answer the teacher's question about the types of triangles, but the answers they give are less comprehensive. These results are in line with research that has been done by Sanapiah $\&$ Juliangkary (2017), that the understanding of the concept of a triangle of students have not fulfilled in the stages of classifying the types of triangles. After analyzing the textbooks and conducting the classroom observations, it turns out that learning designs that happen is not using a physical objects, and students are not given the opportunity to represent themselves about what they observed, then the material structure is not proportional. So that the form of coordination between concepts is definitely not happening. Students do not experience an abstraction process in discovering the concept and experience a classificational misconception.

Then students experience theoretical misconceptions, they experience confusion when determining the height of a triangle when being asked about the area of a triangle. The results of these students' answers are in line with the results of research conducted by Hutagalung, Mulyana, \& Pangaribuan (2020). This misconception occurs to students, because in general they are usually given examples of routine problems. Students are never got a good definition, they are never get the opportunity to construct a definition. Students are only given an explanation, which includes the height or base of a triangle through basic examples. Submission of concepts is very much avoided from the process of abstraction, students are not invited to recall previous experiences relating to the concept of phytagoras and their properties which can further strengthen the concept of the base and height of the triangle, the instructional process avoids direct physical observation, students are not directed to represent what is observed in a geometrical drawing, and at the end, students are not able to coordinate the concept of phytagoras with the height / base of the triangle so that they experience a classificational misconception to solve the area of the triangle. Students experience other theoretical misconceptions and correlational misconceptions, this includes errors in explaining mathematical facts and also connecting 
concepts with one another. Students experience misconceptions because they have to memorize all formula of geometry.

There are several incorrect orientations. The process of abstraction in geometry is not happen. According to Syahbana (2013), the volume of a geometry can be recognized by tracing the shape of the base. In essence, a geometrical structure derives from the broad structure of the base which forms the height of the geometric structure. If there are other irregular spaces, try to form a sketch so that the shape of the base can be recognized. Assuming that this geometry has undergone a transformation in form from its normal form, it is necessary to trace which shape is the base and determine which height. With this process of abstraction, the learning to convey the concept of the volume of geometry will avoid misconceptions.

The material conveyed by the teacher regarding rectangular also about geometry should be designed to be interconnected, when the teacher designs learning well, the learning objectives will be achieved (Kadarisma et al., 2019), so students do not experience confusion in constructing concepts, and the coordination between concepts will be built up, the abstraction process is very instrumental in it. If this is applied, the students of geometry ability will be better and students will not face misconceptions.

From the analysis, we can see some factors that ultimately make students experience misconceptions. Based on this, it appears that students are very isolaeded from the process of abstraction. To overcome this, students should be directed to be able to recognize the properties of geometry by using physical objects or discover it directly, then students must re-know previous experiences related to the concept being faced (for example when studying space construction, review back to the concept of a flat build, the concept of congruence, the concept of alignment, etc.), do not let the students have limited understanding about the prerequisite material. Furthermore, students must be able to represent the results of their thoughts / observations in the form of drawings (specifically geometry), lest students only see, without being able to pour what they see, as a form of analysis carried out on the results of their observations. When drawing, students indirectly do mathematical modeling, students feel which parts of the structure are congruent and analyze the properties of the observations as outlined. Next, students is asked to construct the concept of construction process (put it in the student worksheet), then direct students to be able to develop what they have captured (can be by giving other cases or open ended cases), and coordinating other concepts that similar so that they become a new understanding or new knowledge that is more comprehensive.

Based on the data obtained, it appears that students who experience misconceptions are students who come from the lowest level of abstraction. For students with high levels of abstraction, they generally do not experience misconceptions. Visible relationship between the two, then it becomes a recommendation for researchers so that the process of abstraction occurs to students, thus avoiding students from misconceptions. In order for students to have good mathematical skills, the mathematics teacher as a supporting factor must also have good mathematical skills (Hidayat, 2017). In addition, this abstraction process is closely related to the level of students' geometrical thinking, the abstraction process that is sharpened makes students develop a level of geometrical thinking so students are expected to have a higher level of knowledge in geometry and certainly avoid misconceptions.

\section{CONCLUSION}

Based on research that has been done, it can be concluded that students experience various types of misconceptions. Having analyzed that occur on student misconceptions are closely linked to the ability of abstraction that is owned by the students where the better the 
ability of abstraction, the more students are protected from misconception. The topic taken in this research is the topic of basic geometry, the results can be a source of information for middle school teachers about the types of errors that often occur in students.

\section{REFERENCES}

Adolphus, T. (2011). Problems of teaching and learning of geometry in secondary schools in Rivers State, Nigeria. International Journal of Emerging Sciences, 1(2), 143-152.

Ay, Y. (2017). A Review Of Research On The Misconceptions In Mathematics Education. Education Research Highlights in Mathematics, Science and Technology, 21-31.

Battista, M. T. (2007). The development of geometric and spatial thinking. F. Lester (Ed.), Second Handbook of Research on Mathematics Teaching and Learning (s. 843-908). Charlotte, NC: NCTM. Information Age Publishing.

Dayanti, P., Sugiatno, S., \& Nursangaji, A. (2019). Miskonsepsi siswa dikaji dari gaya kognitif dalam materi jajargenjang di sekolah menengah pertama. Jurnal Pendidikan dan Pembelajaran Khatulistiwa, 8(9).

Fitriani, N. (2018). Proses Abstraksi Matematis Siswa SMP pada Konsep Bangun Ruang Sisi Lengkung melalui Pendekatan Realistic Mathematics Education dengan Model Van Hiele. Bandung: Universitas Pendidikan Indonesia.

Fitriani, N., Suryadi, D., \& Darhim, D. (2018). Analysis of mathematical abstraction on concept of a three dimensional figure with curved surfaces of junior high school students. Journal of Physics: Conference Series, 1132(1), 012037. https://doi.org/10.1088/1742-6596/1132/1/012037

Goodson-Espy, T. (1998). The roles of reification and reflective abstraction in the development of abstract thought: Transitions from arithmetic to algebra. Educational Studies in Mathematics, 36(3), 219-245. https://doi.org/10.1023/A:1003473509628

Hendriana, H., Prahmana, R. C. I., \& Hidayat, W. (2018). Students' performance skills in creative mathematical reasoning. Infinity Journal, $7(2), 83$. https://doi.org/10.22460/infinity.v7i2.p83-96

Hidayat, W. (2017). Adversity quotient dan penalaran kreatif matematis siswa SMA dalam pembelajaran argument driven inquiry pada materi turunan fungsi. KALAMATIKA Jurnal Pendidikan Matematika, 2(1), 15-28. https://doi.org/10.22236/KALAMATIKA.vol2no1.2017pp15-28

Hong, J. Y., \& Kim, M. K. (2016). Mathematical Abstraction in the Solving of Ill-Structured Problems by Elementary School Students in Korea. 12(2), 267-281. https://doi.org/10.12973/eurasia.2016.1204a

Hutagalung, E. E., Mulyana, E., \& Pangaribuan, T. R. (2020). Mathematical abstraction : students ' concept of triangles. Journal of Physics: Conference Series, 1521. https://doi.org/10.1088/1742-6596/1521/3/032106

Kadarisma, G. (2016). Improving Students' Logical Thinking Mathematic Skill Through Learning Cycle 5E and Discovery Learning. Proceeding Of 3rd International Conference on Research Implementation Education Of Mathematics and Science.

Kadarisma, G., Senjayawati, E., \& Amelia, R. (2019). Pedagogical Content Knowledge PreService Mathematics Teacher. Journal of Physics: Conference Series, 1315(1), 012068. https://doi.org/10.1088/1742-6596/1315/1/012068 
Kusmaryono, I., Basir, M. A., \& Saputro, B. A. (2020). Ontological Misconception In Mathematics Teaching In Elementary Schools. Infinity Journal, 9(1), 15-30. https://doi.org/10.22460/infinity.v9i1.p15-30

Novita, R., Prahmana, R. C. I., Fajri, N., \& Putra, M. (2018). Penyebab kesulitan belajar geometri dimensi tiga. Jurnal Riset Pendidikan Matematika, 5(1), 18-29. https://doi.org/10.21831/jrpm.v5i1.16836

Nurhasanah, F. (2018). Mathematical Abstraction Of Pre-Service Mathematics Teachers In Learning Non-Conventional Mathematics Concepts. Bandung: Universitas Pendidikan Indonesia.

Ozerem, A. (2012). Misconceptions in geometry and suggested solutions for seventh grade students. Procedia - Social and Behavioral Sciences, 55, 720-729. https://doi.org/10.1016/j.sbspro.2012.09.557

Sanapiah, \& Juliangkary, E. (2017). Profil Pemahaman Konsep Mahasiswa Ditinjau Berdasarkan Pengalaman Belajar Segitiga. ELPSA Conference, 1(1), 96-105.

Syahbana, A. (2013). Alternatif Pemahaman Konsep Umum Volume Suatu Bangun Ruang. Edumatica, 3(2), 1-7. 